\title{
PENGARUH WORK OVERLOAD DAN WORK FAMILY CONFLICT TERHADAP TURNOVER INTENTION YANG DIMEDIASI OLEH WORK EXHAUSTION
}

\author{
Nurul Hidayatin Nisa \\ Magister Manajemen Universitas Muhammadiyah Malang \\ E-mail:nisa.alhikmah@gmail.com \\ Nazaruddin Malik \\ Fakultas Ekonomi dan Bisnis Universitas Muhammadiyah Malang
}

\begin{abstract}
The purpose of this research was to examine factors that determine turnover intention in medical representative at PT. APL. To be known before that medical representatives have high percentage in turnover. The research using work exhaustion as mediation to determine the relationship between works overload and work family conflict of turnover intention. Research method is quantitative approach in causal research. The analysis tools are AMOS and T-Sobel. Findings of this research are both work overload and work family conflict berpengaruh with work exhaustion and turnover intention, work exhaustion mediated work overload and work family conflict over turnover intention.
\end{abstract}

Keywords: Work overload, Work family conflict, Work exhaustion,

Turnover intention

\begin{abstract}
Abstrak
Tujuan dari penelitian ini adalah untuk menguji faktor-faktor yang mempengaruhi turnover intention pada tenaga medis di PT. APL. Telah diketahui sebelumnya bahwa tenaga medis mempunyai persentase turnover yang tinggi. Penelitian ini menggunakan work exhaustion sebagai mediasi untuk mengetahui hubungan antara work overload dan work family conflict terhadap turnover intention. Metode yang digunakan dalam penelitian ini adalah metode kuantitatif dalam kausal research. Alat analisis yang digunakan adalah AMOS dan T-Sobel. Temuan penelitian ini adalah work overload dan work family conflict berpengaruh terhadap work exhaustion dan turnover intention. Work exhaustion adalah mediasi work overload dan work family conflict mediasi atas turnover intention.
\end{abstract}

Katakunci: Work overload, Work family conflict, Work exhaustion, Turnover intention 
Penelitian empiris mengenai turnover intention karyawan telah banyak dilakukan untuk mengetahui faktorfaktor yang menyebabkannya.

Moore (2000) mengidentifikasi faktor-faktor yang mempengaruhi turnover intention sehingga dapat mengurangi efek negatif yang dihasilkan dan menjadi alat efektif untuk menurunkan angka turnover. Para peneliti telah menggali berbagai anteseden yang mempengaruhi turnover intention, antara lain tingkat kepuasan, kinerja karyawan, komitmen organisasi, dan kelelahan kerja (work exhaustion).

Dijelaskan dalam banyak literatur bahwa tingkat kepuasan, kinerja dan komitmen terhadap organisasi bersifat konstan terhadap turnover intention. Namun pada work exhaustion hubungan tersebut tidak bersifat dominan, karena karakteristik pekerjaan dan individu sangat mempengaruhi terjadinya kelelahan pada pekerja.

Konsep work exhaustion dicetuskan oleh Moore (2000) menggabungkan konsep tedium dan burnout yang terjadi pada pekerja. Beberapa peneliti seperti Ahuja, Kacmar et al. (2007), Chawla et.al (2011) meneliti dampak job related yang mempengaruhi terjadinya work exhaustion, seperti work overload, role conflict, job autonomy, social support, role ambiguity, work family conflict dan reward. Hasil dari penelitian terdahulu adalah adanya dua prediktor dominan terhadap work exhaustion yaitu work overload dan work family conflict.

Work overload merupakan salah satu stressor dalam lingkungan pekerjaan. Kondisi ini muncul ketika karyawan harus berhadapan dengan banyak pekerjaan dan waktu yang terbatas. Moore (2000) menyatakan bahwa work overload menjadi stressor utama yang menyebabkan work exhaustion. Work overload secara empiris ditemukan berhubungan positif dengan keinginan berpindah.

Honeycutt, Jr. et al. (2009) membandingkan tingkat turnover intention pada 675 marketing dari delapan perusahaan yaitu: manufaktur, jasa keuangan, asuransi, distributor, dan pelayanan industri. Hasilnya adalah pekerjaan yang paling tinggi menghadapi tekanan untuk berpindah adalah pekerja industri dengan posisi jabatan sales representative. Posisi ini dinilai mempunyai tekanan yang tinggi karena harus bekerja dalam target yang tinggi dalam waktu yang terbatas.

Penelitian ini adalah penelitian pertama yang menggabungkan work overload dan work family conflict terhadap turnover intention melalui work exhaustion dengan menggunakan hubungan langsung dan tidak langsung pada karyawan medical representative.

Penelitian dilakukan pada Medical Representative (MR) pada perusahaan farmasi yang berkantor di PT. APL. Tingkat turnover di PT. APL mencapai $40 \%$ setiap tahunnya. Sehingga perusahaan menggunakan banyak waktu dan materi untuk melakukan perekrutan karyawan tiap tahunnya.

Penelitian Kardkarnklai (2014) menjelaskan tingkat turnover yang terjadi pada karyawan MR adalah $16.9 \%$, presentase ini lebih tinggi dibanding industry lain yang rata-rata hanya $11.9 \%$. Penyebabnya adalah culture perusahaan yang menyebabkan tingkat komitmen karyawan rendah. Peneliti memilih medical (sales) representative karena MR mempunyai karakter pekerjaan dengan target kerja 
yang tinggi dan beban kerja yang berlebih. MR dituntut untuk detailing dokter, survai apotik, administrasi kantor yang melebihi kapasitas untuk menyelesaikannya. Tuntutan pekerjaan ini dapat mengganggu kehidupan keluarganya. Karyawan pun merasa kelelahan karena tekanan perusahaan.

Salah satu solusi untuk mengakhiri masalah tersebut adalah karyawan merasa perlu mencari pekerjaan yang sesuai dengan kapasitas mereka. Hal inilah yang mendukung terjadinya work overload, work family conflict, work exhaustion, dan turnover intention pada MR.

Imam Quresi (2013) menyebutkan bahhwa work overload berpengaruh positif signifikan terhadap turnover intention. MR dituntut untuk dapat mencapai target perusahaan. Apabila target tidak terpenuhi maka perusahaan akan melakukan evaluasi pada karyawan. Evaluasi dapat berupa relokasi karyawan ataupun surat peringatan. Hal ini yang membuat MR merasa di bawah tekanan sehingga mencari solusi dengan meninggalkan perusahaan.

Karyawan MR mempunyai karakteristik pekerjaan di lapangan dengan jam kerja panjang meliputi: target call harian yang dibebankan perusahaan, survai apotik, entertaint dokter, sponsorship, dan administrasi laporan hasil kerja. Target kerja yang terlalu tinggi inilah yang membuat MR merasa di bawah tekanan yang menyebabkan work exhaustion. Jarak tempat kerja dengan tempat tinggal yang terlampau jauh serta waktu kerja yang panjang menyebabkan karyawan merasa work exhaustion.

Sedangkan work family conflict merujuk kepada bentuk konflik antarperan yang terjadi ketika tuntutan pekerjaan dan keluarga saling tidak kompatibel dan tidak bisa disejajarkan (Ahuja et al, 2007).

Menurut Greenhaus and Beutall (1985) work family conflict dihasilkan oleh tekanan bersamaan antara peran pekerjaan dan keluarga yang bertentangan satu sama lainnya. Work family conflict terjadi ketika seseorang harus melaksanakan multi peran, yaitu sebagai karyawan, pasangan (suami atau istri) dan orang tua. Tekanan dalam lingkungan kerja yang dapat menimbulkan work family conflict, antara lain tidak teraturnya atau tidak fleksibelnya jam kerja, overload pekerjaan, perjalanan dinas yang banyak, konflik antar individu karyawan dan tidak adanya dukungan dari supervisor atau perusahaan. Tekanan dalam lingkungan keluarga yang dapat menghasilkan work family conflict, antara lain kehadiran anak yang paling kecil, tanggung jawab utama terhadap anak, tanggung jawab sebagai anak yang tertua, konflik antar anggota keluarga dan tidak adanya dukungan dari anggota keluarga.

Medical representative adalah pekerjaan lapangan dengan jam kerja yang panjang sehingga karyawan kesulitan memenuhi kewajibannya dalam keluarga. Simposium dan pekerjaan yang harus dilakukan pada hari libur membuat MR memiliki waktu yang sedikit untuk keluarga.

Karyawan dari luar kota pun kesulitan untuk menyeimbangkan antara tuntutan sebagai anggota keluarga dan tuntutan perusahaan.

Hal ini didukung penelitian terdahulu oleh Chawla dan Shondi. (2011) yang menyatakan bahwa work family conflict dipandang sebagai faktor situasi dimana pekerja tidak dapat 
menyeimbangkan antara tuntutan pekerjaan dengan tuntutan keluarga, sehingga karyawan mengalami kelelahan kerja dalam usahanya memenuhi tuntutan tersebut.

Morthati and Kumar (2014) menyatakan bahwa status pernikahan juga sangat mempengaruhi MR dalam mengambil keputusan untuk keluar dari pekerjaan. Sehingga diketahui bahwa status pernikahan MR berpengaruh signifikan terhadap turnover intention.

Job Burnout didefinisikan oleh Maslach dan Jackson (1981) sebagai hasil tekanan emosi yang konstan atau berulang dalam waktu yang lama di tempat kerja. Sementara work exhaustion adalah keletihan fisik, emosi dan mental yang disebabkan karena tekanan kerja dalam jangka waktu yang panjang (Moore, 2000). Jadi dapat disimpulkan bahwa job burnout merupakan bagian dari work exhaustion.

Penelitian ini fokus pada work exhaustion karena: (1) work exhaustion merupakan varibel unik karena mempengaruhi variabel lain bedasarkan karakteristik dari pekerjaan. (2) work exhasution berdampak negatif pada karyawan karena meningkatkan perpindahan karyawan, ketidak hadiran dan mengurangi produktifitas.

Pemahaman mengenai work exhaustion dalam lingkungan Medical representative akan membantu manajemen dalam mengurangi pengaruh negatifnya pada perusahaan.

Penelitian terdahulu menunjukkan bahwa work exhaustion sebagai antecedent dominan dari keinginan berpindah tenaga kerja (Chawla, 2011; Ahuja et al., 2007).

\section{Metode Penelitian}

Metode penelitian pada penelitian ini digunakan untuk menjawab hipotesis sebagai berikut:

H1: Work overload berpengaruh positif terhadap work exhaustion.

$\mathrm{H} 2$ : Work family conflict berpengaruh positif terhadap work exhaustion.

H3: Work overload berpengaruh positif terhadap turnover intention.

H4: Work family conflict berpengaruh positif terhadap turnover intention.

H5: Work exhaustion berpengaruh positif terhadap turnover intention.

H6: Work exhaustion memediasi work overload dan work family conflict terhadap turnover intention.

Adapun penelitian ini menggunakan pendekatan kuantitatif dan jenis penelitian kausal yaitu penelitian dengan bentuk hubungan yang bersifat sebab-akibat.

Teknik analisis dalam penelitian ini dibagi menjadi dua yaitu analisis deskriptif dan analisis inferensia. Analisis deskriptif menggunakan statistik rata-rata (MEAN) dengan kategori berdasarkan Tree-box Method. Sedangkan analisis inferensia menggunakan AMOS versi 16.0. dan untuk menganalisis hubungan mediasi mengunakan uji tes sobel.

Populasi dari penelitian ini adalah adalah karyawan medical representativeyang berkantor di PT. APL sebanyak 300 orang. Penelitian ini menggunakan teknik propotionate stratified random sampling. Dengan tingkat signifikansi sebesar $5 \%$, maka diperoleh jumlah sampel adalah sebesar 
146 responden. Teknik peng-umpulan data dilakukan dengan meny-ebar langsung lembar kuisioner pada 146 responden di kantor APL dan di rumah sakit.

Hasilnya sebanyak 118 kuisioner kembali kepada peneliti.Dalam penelitian ini dapat dikelompokan menjadi variabel independen yaitu variabel work overload dan variabel work family conflict. Variabel dependen yaitu variabel turnover intention dan variabel work exhaustion.

\section{Hasil Penelitian dan Pembahasan}

Karakteristik responden dalam penelitian ini dibagi menjadi tiga, yaitu (1) responden berdasarkan jenis kelamin, (2) responden berdasarkan masa kerja, (3) responden berdasarkan pendidikan. Jumlah responden MR berjenis kelamin laki-laki adalah 82 orang $(70 \%)$ sedangkan MR berjenis kelamin perempuan adalah 36 orang (30\%).

Responden berdasarkan masa kerja 1-5 tahun sebanyak 37 orang atau $31 \%$, sedangkan responden dengan masa kerja diatas 15-20 tahun sebanyak 8 orang atau $0.6 \%$. Res-ponden berdasarkan pendidikan SMA sebanyak 25 orang atau $21 \%$. Res-ponden berpendidikan D3/D2/D1 seba-nyak 39 orang atau 33\%. Responden berpendidikan Sarjana (S1) sebanyak 54 orang atau sebesar $45 \%$.

Penilaian responden atas masingmasing variabel penelitian dapat dijelaskan dengan melihat hasil pengolahan statistika deskriptif yang menunjukkan bahwa nilai mean (rata-rata) variabel work overload sebesar 3.78, variabel work family conflict sebesar 3.67, variabel work exhasution sebesar 4,13 , dan variabel turnover intention sebesar 4,48. Maka dapat disimpulkan bahwa semua variabel dirasa tinggi oleh karyawan dan tidak terjadi autokorelasi.

Hasil analisis AMOS dalam penelitian ini dibagi dalam analisis uji konfirmasi full model meliputi uji nilai CR ratio, uji konvergent validity dan reability, uji multivariate outlier, uji normalitas. Kemudian analisis stuctural equation modelling.

Hasil dari uji konfirmasi full model dapat diketahu nuilai $\mathrm{CR}$ ratio dari semua indikator variabel mempunyai nilai p-value sebesar 0.000 hal ini membuktikan bahwa indikator tersebut membentuk variabel latennya secara signifikan, dilihat dari $\mathrm{p}$-value yang dihasilkan $<0.050$.

Hasil uji validitas diketahui nilai standardized loading factors pada semua indikator variabel $>0,40$ sehingga dapat dikatakan tersebut mempunyai validitas yang baik.

Hasil uji nilai construct Reliability tiap konstruk adalah $>0.40$ sehingga dapat dinyatakan bahwa model reliabel karena nilai construct Reliability. Hasil dari uji multivariate outlier diketahui bahwa jarak Mahalanobis maksimal adalah 33,439 (Chisquare $17=39.252$ ) sehingga dapat disimpulkan bahwa tidak terdapat multivariate outliers.

Hasil dari uji normalitas diketahui nilai CR dari skewness dan kurtosis sebagian besar indikator berada didalam selang $\pm 2,58$, hanya pada Ti1 lebih dar 2,58 namun secara multivariate multivariate nilai $\mathrm{CR}$ masih menunjukkan distribusi yang normal yaitu $0,87 .(<2,58)$. 
Ekonomika-Bisnis,Vol. 7 No. 1 Bulan Januari Tahun 2016 Hal 67-76

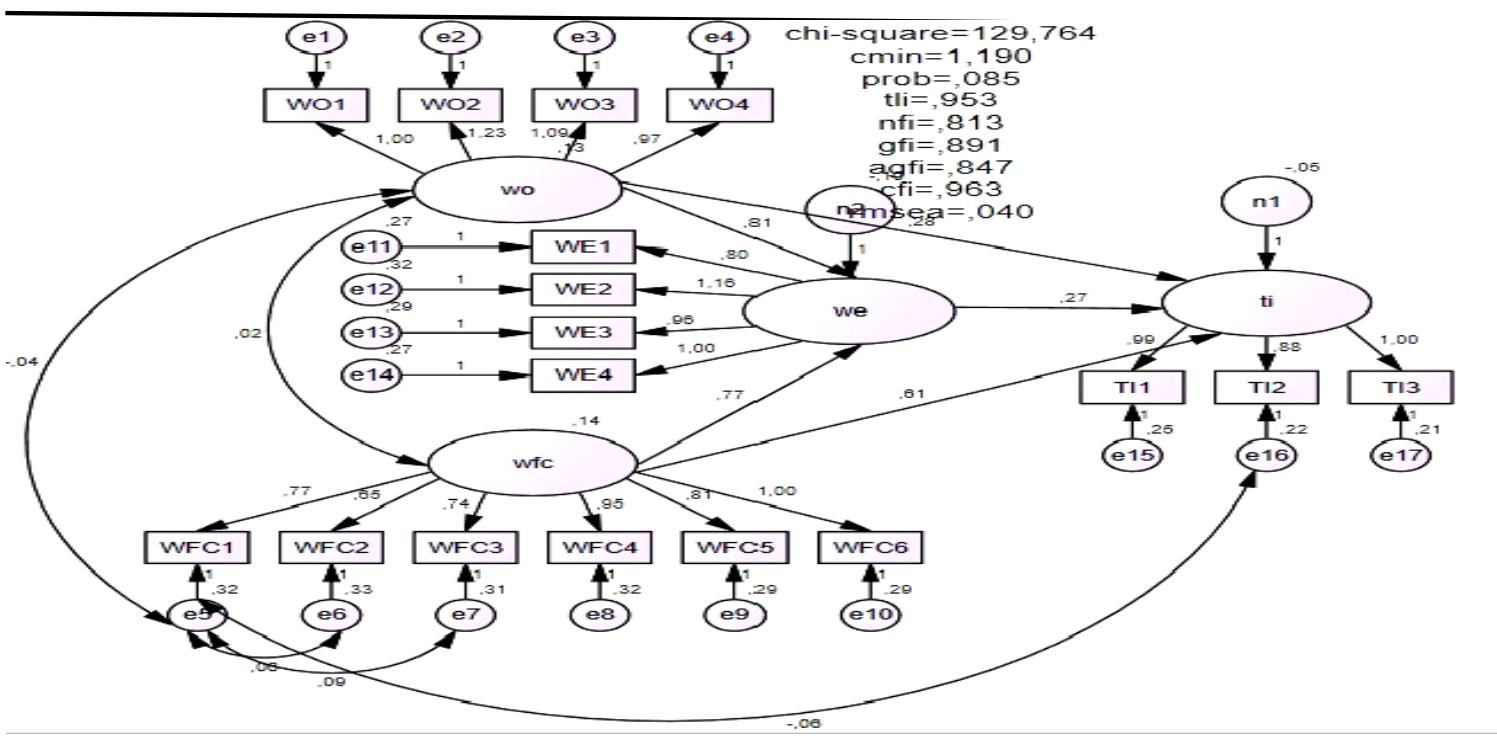

Sumber : Data diolah

Gambar 1. Full Model Structural Equation Modeling

Tabel 1. Hasil Goodness of Fit Indices Modell

\begin{tabular}{cll}
\hline Kriteria & Hasil & Nilai Kritis \\
\hline Cmin/df & 1.190 & $\leq 2,00$ \\
Probability & 0.85 & $\geq 0,05$ \\
RMSEA & 0,040 & $\leq 0,08$ \\
GFI & 0.891 & $\geq 0,90$ \\
AGFI & 0,847 & $\geq 0,90$ \\
TLI & 0.953 & $\geq 0,95$ \\
CFI & 0.963 & $\geq 0,95$ \\
\hline
\end{tabular}

Sumber : Data diolah

Tabel 2.Hasil Loading Factor Stuctural Equation Modelling

\begin{tabular}{ccccccc}
\hline \multicolumn{2}{l}{ Pengaruh hubungan } & & Estim & S.E. & C.R. & P \\
& & & & & & \\
\hline We & $<---$ & Wo &, 858 &, 163 & 5,267 & 0.00 \\
$\mathrm{We}$ & $<--$ & Wfc &, 765 &, 145 & 5,261 & 0.00 \\
$\mathrm{Ti}$ & $<---$ & We &, 236 &, 086 & 2,744 & 0.006 \\
$\mathrm{Ti}$ & $<---$ & Wo &, 320 &, 105 & 3,045 & 0.002 \\
$\mathrm{Ti}$ & $<---$ & Wfc &, 625 &, 120 & 5,191 & 0.00 \\
\hline
\end{tabular}

Sumber : Data diolah 
Pengaruh Work Overload Dan Work Family ...( Nurul Nisa, Nazaruddin Malik)

Tabel 3. Hasil Sobel test Work overload-work exhaustion-turnover intention

\begin{tabular}{llll}
\hline Variabel & Test statis & Std Error & P-value \\
\hline Work overload & 2.432 & 0.0831 & 0.0149 \\
Work & 2.398 & 0.0843 & 0.0164 \\
exhasution & & & \\
& 2.468 & 0.0819 & 0.0135 \\
\hline
\end{tabular}

Sumber : Data diolah

Tabel 4. Hasil Sobel test Work family conflict-work exhasution-turnover intention

\begin{tabular}{llll}
\hline Variabel & Test statis & Std Error & P-value \\
\hline $\begin{array}{l}\text { Work family- } \\
\text { conflict }\end{array}$ & 2.434 & 0.0741 & 0.0149 \\
& & & \\
Work exhaustion & 2.400 & 0.0751 & 0.0163 \\
& & & \\
& 2.469 & 0.0731 & 0.0135 \\
& & & \\
\hline
\end{tabular}

Sumber : Data diolah

Pada tabel 1 hasil uji kelayakan model didapatkan nilai $p$-value lebih dari $0,05(5 \%)$ hal ini menunjukkan matriks varian-kovarian populasi sama dengan matriks varian-kovarian model yang diestimasi, dengan kata lain model sesuai. Selain itu juga, dilihat semua kriteria memenuhi batas cut off value yang ditentukan. Sehingga memenuhi good of fit. Setelah didapatkan model yang sesuai, selanjutnya dapat dilihat signifikansi dari model tersebut dengan membandingkan nilai probabilitas dari setiap hubungan kausalitas dengan $\alpha$ $(5 \%)$.

Pada tabel 2 diketahui bahwa work overload berpengaruh signifikan terhadap work exhaustion, dilihat dari nilai p-value 0.00 atau kurang dari $5 \%$ dan nilai CR 5,267 atau lebih dari 1.96. Work family conflict berpengaruh signifikan terhadap work exhaustion, dilihat dari nilai p-value 0.00 atau

kurang dari 5\% dan nilai CR 5,261 atau lebih dari 1.96.

Work overload berpengaruh signifikan terhadap turnover intention, dilihat dari nilai p-value 0.00 atau kurang dari 5\% dan nilai CR 3,045 atau lebih dari 1.96. Work-family conflict berpengaruh signifikan terhadap turnover intention, dilihat dari nilai $\mathrm{p}$ value 0.00 atau kurang dari $5 \%$ dan nilai CR 5,191 atau lebih dari 1.96.

Work exhaustion berpengaruh signifikan terhadap turnover intentions, dilihat dari nilai p-value 0.00 atau kurang dari 5\% dan nilai CR 2,744 atau lebih dari 1.96.

Untuk mengukur signifikan dari koefisien efek tidak langsung (mediasi) dapat menggunakan software yang dikembangkan oleh Sobel (1982) yang lebih dikenal dengan Sobel test. Hasil Sobel test dalam penelitian ini adalah pada tabel 3 . 
Work exhaustion memediasi pengaruh work overload dan work exhaustion terhadap turnover intentions, dilihat dari nilai $\mathrm{p}$-value 0.0135 atau kurang dari $5 \%$ dan nilai test statistik 2.468 atau lebih dari 1.96 .

Work exhaustion memediasi pengaruh work family conflictdan work exhaustionterhadap turnover intentions, dilihat dari nilai p-value 0.013 atau kurang dari $5 \%$ dan nilai test statistik 2.469 atau lebih dari 1.96.

Bedasarkan hasil analisis menunjukan pengaruh positif signifikan antara variabel work-family conflict dan turnover intention. Hal ini sesuai dengan hipotesis peneliti yang menyatakan bahwa work overload berpengaruh signifikan terhadap turnover intention. Penelitian ini mendukung dari penelitian yang dilakukan oleh Saragih (2000) yang menyatakan bahwa work-family conflict adalah konflik berefek fatal dan cenderung membuat seseorang untuk meninggalkan pekerjaannya.

\section{Penutup}

Berdasarkan hasil penelitian ini, Medical representative di PT. APL mengalami work overload atau beban kerja yang berlebih akibat dari pekerjaan dalam waktu yang panjang dan mobilitas yang tinggi. Sehingga medical representative menganggap penugasan perusahaan tidak sesuai dengan kapasitas mereka.

Beban pekerjaan yang berlebih yang terus dikerjakan akan meningkatkan kelehan kerja yang berkepanjangan pada karyawan (work exhasution). Work overload yang tidak bisa ditoleransi akan meningkatkan keinginan karyawan untuk berpindah (turnover intention). Pada penelitian ini diketahui bahwa work overload menjadi faktor dominan karyawan mengalami kelelahan kerja. Beban kerja yang tidak sesuai dengan kapasitas karyawan juga akan menimbulkan work-family conflict.

Bedasarkan hasil penelitian, peneliti dapat memberikan beberapa saran sebagai berikut: Perusahaan diharapkan memberikan beban pekerjaan yang sesuai dengan kapasitas karyawan. Seiring dengan penambahan beban kerja maka perusahaan perlu menambah jumlah tenaga kerja yang dibutuhkan. Hal ini bertujuan agar beban kerja dapat berkurang dan tidak menyebabkan kelelahan pada karyawan ataupun keinginan karyawan untuk berhenti dari perusahaan.

Dalam menanggapi konflik yang disebabkan oleh work-family conflict, perusahaan dapat memberikan perhatian kepada keluarga karyawan sehingga dapat memotivasi karyawan dalam bekerja. Sebagai contoh pemberian ucapan atas kelahiran, pernikahan, atau berita duka yang berhubungan dengan keluarga, atau memberikan parcel ketika hari raya, atau mengadakan Family Gathering. Tentunya hal tesebut akan membuat karyawan merasa bahwa perusahaan sangat memperhatikan kehidupan keluarga mereka dan pada akhirnya dapat mengurangi keinginan medical representative untuk berpindah.

Untuk mengurangi work exhaustion, perusahaan perlu membuat sistem kompensasi penjualan yang adil dan progesif, reward bedasarkan kinerja, ataupun kenaikan level jabatan karyawan. Bagi peneliti selanjutnya, dapat dilakukan di perusahaan jasa atau pelayanan, misal pendidikan dan perbankan. Peneliti selanjutnya dapat menambahkan dan memodifikasi indikator yang peneliti gunakan. 
Pengaruh Work Overload Dan Work Family ...( Nurul Nisa, Nazaruddin Malik)

\section{DAFTAR PUSTAKA}

Ahuja, m.k., chudoba, k.a., kacmar, c.j.

2007. It road warriors: balancing work-family conflict, job autonomy, and work overload to mitigate turnover in tentions, mis quarterly, vol. 31, no.1, march, pp.1-17.

Ahuja, m.k. 2002. Women in the information technology profession: a literature review, synthesis and research agenda. European journal of information systems (11:1), hlm.20-34.

Ahuja, m., et al. 2002. "Overworked and isolated? Predicting the effect of work family conflict, autonomy, and workload on organizational commitment and turnover of virtual workers. Proceedings of the 35th hawaii international conference on system sciences 24(5): 132-156.

Chawla, Deepak dan Neena S. 2011. Assessing the Role of Organizational and Personal Factors in Predicting Turnover Intentions: a Case of School Teachers and BPO Employees (online) vol 38, no. 02

Cordes, c. L. And t. W. Dougherty .1993. A review and an integration of research on job burnout. Academy of management review. 18(4): 622-656.

Earl d. Honeycutt, et al. 2009. Turnover in the sales force: a comparison of hunters and farmers. Journal of

Ferdinand. 2002. Structural equation modeling dalam penelitian. Semarang: Universitas Diponegoro

Ghazali. 2012. Structural Equation Modeling: Metode Alternatif dengan AMOS. Semarang: Universitas Diponegoro

Greenhaus, j. H., dan beutall, n. J. 1985. Sources of conflict between work and family roles. Academy of management review, 10(1), 7688. (online) vol. 3 , no. 2 ,

Maslach and s. E. Jackson. 1984. Burnout in Organizational Settings. Applied social psychology annual: applications in organizational settings. journal industry (133-153).

Moore, Jo Ellen. 2000. One road to turnover: an examination of work exhaution on technology proferssionals. Vol. 24. No. 01.

Saragih, Susanti R. 2009. Pengaruh Work Exhaustion terhadap Keinginan Berpindah: Studi pada Tenaga Kerja IT di Indonesia.

Simamora. 2002. Panduan Riset Perilaku Konsumen. Jakarta: PT. Gramedia Pustaka Utama.

Simamora dan Henry. 1997. Manajemen Sumber Daya Manusia. Yogyakarta: STIE YKPN 
Ekonomika-Bisnis,Vol. 7 No. 1 Bulan Januari Tahun 2016 Hal 67-76

Sugiono. 2012. Statistika untuk

Peneliti. Bandung: PT. Alfabeta 